\title{
Alberta Health Services
}

\section{Adult Urologist}

The Department of Surgery, Alberta Health Services - Calgary Zone and the University of Calgary invite applications for a one year locum Adult Urologist at the Southern Alberta Insitute of Urology.

Qualifications include an MD and a Fellowship in the Royal College of Physicians and Surgeons of Canada in Urology. Applicants must be eligible for licensure in the province of Alberta.

The successful candidate will have locum status in the Section of Urology. Duties will include patient care to the community of Calgary and surrounding areas. Teaching at the undergraduate and post graduate level will be required. Participation in research related to clinical outcomes or medical education is expected. Successful applicants will take call according to the site and Alberta Health Services policies.

In accordance with Canadian immigration requirements, priority will be given to Canadian citizens and permanent residents of Canada. Alberta Health Services and the University of Calgary are committed to employment equity.

Please submit a letter of application, your curriculum vitae and three letters of reference by May 14, 2014 to:

Kevin V. Carlson, MD FRCSC DABU

Section Chief of Urology, Department of Surgery

University of Calgary

Suite $66087007-14^{\text {th }}$ Street SW

Calgary AB Canada

T2V $1 \mathrm{P} 9$ 